\title{
A Compensatory Response to the Problem of Evil
}

\author{
Michael Douglas Beaty
}

check for

updates

Citation: Beaty, Michael Douglas. 2021. A Compensatory Response to the Problem of Evil. Religions 12: 347 https://doi.org/10.3390/rel12050347

Academic Editors: James Sterba and Paul Morris

Received: 30 March 2021

Accepted: 9 May 2021

Published: 13 May 2021

Publisher's Note: MDPI stays neutral with regard to jurisdictional claims in published maps and institutional affiliations.

Copyright: (C) 2021 by the author. Licensee MDPI, Basel, Switzerland. This article is an open access article distributed under the terms and conditions of the Creative Commons Attribution (CC BY) license (https:/ / creativecommons.org/licenses/by/ $4.0 /)$.
Department of Philosophy, Baylor University, Waco, TX 76798-7273, USA; michael_beaty@baylor.edu

Abstract: In this essay, I affirm the univocity thesis while discussing some alternative positions that avoid the problem of evil by rejecting the univocity thesis. I reject Sterba's assumption that God's governance of creation is adequately understood as an analogy to good governance of a politically liberal democracy. I suggest that Sterba's commitment to the Pauline principle forces a dilemma between significant human freedom and meticulous divine intervention. Finally, I argue that the existence of horrendous evils is logically compatible with the existence of a good God, given a compensatory response to the problem of evil.

Keywords: univocity thesis; doctrine of divine transcendence; horrendous evils; compensatory response to the problem of evil; Marilyn McCord Adams; Thomas Aquinas; Karl Barth; Brian Davies; Duns Scotus; James Sterba

In Is a Good God Logically Possible?, James Sterba raises a familiar, and oft-raised, objection to the existence of God, a maximally perfect Being: Whether the existence of God is compatible with the degree and amount of evil actually that exists in our world. ${ }^{1}$ While acknowledging the significance of Alvin Plantinga's free will defense as a response to this traditional philosophical issue for Christian theists, Sterba finds two significant faults with free will defenses to the problem of evil. First, they fail to address not only the vast amount of evils but also the degree/kinds of evils that actually exist in our world. Following Marilyn Adams ${ }^{2}$ and Sterba ${ }^{3}$, let us refer to particularly grievous evils as "horrendous evils". Specifically, Sterba concedes that a good God ${ }^{4}$ may have morally sufficient reasons for allowing some kinds and amounts of evils, but clearly, it is not possible that a good God is permitted to allow the vast amount and kinds of horrendous evils of which we are so aware. Second, the familiar kinds of defenses fail to grapple with the ethical concepts and issues that are relevant to the discussion of the existence of horrendous evils. Sterba argues that the existence of horrendous evils is logically inconsistent with the existence of a God understood as a good God, once we acknowledge the ethical implications of God having these properties. In this paper, I argue that Sterba fails to make his case.

I found Sterba's book an engaging and formidable book, both in terms of the range of traditional and contemporary topics he addresses and some of the new conceptual or ethical resources to which he appeals to make his case. In this essay, frankly, I cannot do justice to the full range of provocative issues he raises and theses he prosecutes. I will limit my attention to only a few of his primary arguments.

\section{Univocity Thesis and the Goodness of God}

Let me begin identifying a theme about which Sterba and I agree-that typically, when theists acknowledge or affirm God's goodness or worry about His goodness, moral goodness is being ascribed to God in the same sense in which we ascribed moral goodness to human beings (and other possible moral agents). ${ }^{5}$ Call this the univocity thesis. Sterba reminds his readers that important thinkers in the Western philosophical and theological tradition have contended that God is not a moral agent. Additionally, if this thesis is true, then the problem of evil cannot get off the ground. Brian Davies is one such contemporary example. He says, 
As it is usually presented, the problem of evil is a problem which arises on the assumption that if God exists, he must be morally good. Hence, it is that writers like Swinburne and Hick to deal with it by attempting to exonerate God from the moral point of view in spite of the existence of evil. But now suppose we introduce a new question into the discussion. Suppose we ask whether the theist is bound to regard God as a moral agent. Once we do this a whole new line of defense is open to someone who thinks it is reasonable to believe in the existence of God along with the existence of evil. For, clearly, if belief in God is not necessarily belief in the existence of a moral agent, then the problem of evil $\ldots$ it turns into a pseudo-problem. ${ }^{6}$

According to Davies, the concern that the existence of evil, horrendous or not, is an objection to the existence of God reflects a confused way of thinking about God, a category mistake ${ }^{7}$ since God is not a moral agent. Why think that God is not a moral agent? Davies offers this response:

... classical theism thinks of God as the source of all beings ... But if God is the source of all beings, something has to be done to distinguish him from all beings, and the obvious thing to do is to deny that God is a being. Yet moral agents, whether bad or good, are obviously beings. If God is not, in terms of classical theism, properly spoken of as a being, he is not properly spoken of as a moral agent ${ }^{8}$

In a more recent book, Davies argues that the problem of evil is a pseudo-problem because those who pose it as a real problem for theism fail to understand the affirmation of God's goodness properly. Appealing to the thought of Thomas Aquinas, Davies insists that the goodness of God is predicated analogically rather than univocally with respect to the moral goodness of human beings. It is a mistake, argues Davies, to think (or assume) that if God's goodness is understood as perfection, a predicate, 'moral goodness', a property that both God and human beings may possess in the same way. In short, Davies argues that the model of the morally well-formed human being is an inadequate model for understanding Divine Goodness. ${ }^{9}$

Karl Barth, an important Protestant Theologian of the 20th century, concurs with Davies. He argued that since

[God] is distinct from everything, ... He is so in a peculiar and pre-eminent fashion, ... as no created being confronts any other ... God stands at an infinite distance from everything else, not in the finite degree of difference with which created things stand towards each other. ${ }^{10}$

In another passage, Barth says, "Between God and man, as between God and creature in general there exists an irrevocable otherness."11 What Barth's claim consists in is this: God is metaphysically unique compared to all other created objects. Let us call this the doctrine of transcendence. However, this claim about divine transcendence is ambiguous between two possibilities. Does God's metaphysical uniqueness consist in the fact that God is wholly dissimilar to all creatures that exist? That is, that God possesses no properties possessed by any other created object? This seems to be the point suggested by Karl Barth's second quote. Or does God possess some properties possessed by other various particular instances of the kinds of created objects with which we are familiar in the universe, but in ways and degrees that, nonetheless, are unique to God alone? The latter might satisfy the first quote from Barth.

To be sure, the first understanding, but not the second, poses a deep difficulty for traditional or classical Christian theism. The Old and New Testaments use many of the concepts at work in our ordinary moral language when we speak of God's goodness. God is loving, just, and merciful, for example. If these terms refer to properties God has but are entirely different in kind to the moral properties potentially possessed by human beings, then it is reasonable to claim that they are inaccessible, unknowable by us. C. B. Martin captures this difficulty as a dilemma. ${ }^{12}$ 
Argument A: Divine Transcendence and A Dilemma in Speaking About God's Goodness

(1) Either God's goodness is completely different in kind from the kind(s) of moral goodness we admire in ourselves or other human beings, or it is the same kind of moral goodness we admire in ourselves or other human beings.

(2) If it is completely different in kind from the kind(s) of moral goodness we admire in ourselves and other human beings, then God's goodness is unintelligible to us.

(3) If it is the same kind of moral goodness we admire in ourselves or other human beings, the God's goodness is intelligible to us.

(4) Therefore, either God's goodness is unintelligible to us or God's goodness is intelligible to us.

In all fairness, Davies does not argue that Divine Goodness is completely different from the kind of goodness we admire in exemplary human moral agents. The goodness attributed to God and human beings is predicated analogically, not univocally. Davies claims to be interpreting Aquinas on this point and uses Aquinas' authority as one reason, perhaps, to not only accept but to insist on an analogical understanding of Divine Goodness for Christian theists. However, supposing that appeals to authority are legitimate, my colleague Dr. Thomas Ward argues, persuasively to my mind, that there is no substantive difference between Scotus' appeal to univocity and Aquinas' appeal to analogy. The central insight of Scotus' univocity thesis with respect to speaking about God is that

the standards of good reasoning about God are exactly the same standards for good reasoning about anything. Piety does not excuse fallacies. The theory of univocity holds that some of our words mean exactly the same thing as when used of God as they mean when used of creatures. ${ }^{13}$

Aquinas seems to affirm Scotus' affirmation.

Neither is all predication purely equivocal, as some have said, since this would entail that nothing can be known or demonstrated about God, but rather would always be subject to the fallacy of equivocation. This would be contrary to the philosophers, who prove many things about God through demonstration. ${ }^{14}$

In A Grief Observed, C. S. Lewis agonizes over the death of his wife Joy, a death brought about by a battle with cancer and from which she suffered mightily. Lewis had come to marriage late in life, and his courtship, and later marriage, of Joy brought to him a life he had not imagined possible for himself and joys he had never experienced. In one passage in the short book, Lewis says, "Sooner or later I must face the question in plain language. What reason have we, except our own desperate wishes, to believe that God is, by a standard we can conceive, 'good'? Doesn't all the prima facie evidence suggest exactly the opposite?"15 Lewis recognizes that one way out is to say that God is so exalted and we human beings

are so depraved that our ideas of goodness count for nothing; or worse than nothing - the very fact that we think something good is presumptive evidence that it is really bad. The word good, applied to Him, becomes meaningless: like abracadabra. [However, if so] ${ }^{16}$ We have no motive for obeying Him ... If cruelty is from His point of view 'good,' telling lies may be 'good' too ... If His ideas of good are so very different from ours, what He calls Heaven might well be what we should call Hell, and vice versa. Finally, if reality at its very root is so meaningless to us-or, putting it the other way round, if we are such total imbeciles-what is the point of trying to think either about God or about anything else? This knot becomes undone when you try to pull it tight. ${ }^{17}$

Thus, Lewis affirms that we must speak of the moral goodness of human beings and God's moral goodness univocally. According to Lewis, we are undone to speak non-univocally of God's moral goodness. If Lewis is correct, and I believe he is, then it follows that Christians and Jews are committed to God's metaphysical uniqueness but not in the strong sense. 
Indeed, one of the most important theological claims made in the Hebrew and Christian scriptures is that human beings are created in the image of God. That God is wholly dissimilar to all creatures, including human beings, is logically inconsistent with the claim that human beings are created in the image of God. ${ }^{18}$ In addition, in the Hebrew and Christian scriptures, God is spoken of as being just, loving, patient, long-suffering, good to human beings, etc. Moral predicates are applied to God, it appears to me, univocally rather than non-univocally. Thus, like Sterba, I accept the univocity thesis in thinking about Divine Goodness-the goodness of God. ${ }^{19}$

\section{God's Governance of the Universe and Politically Liberal Societies}

Sterba begins his book with a discussion of the free will defense. ${ }^{20}$ He observes that political states, particularly those aiming at securing a high level of justice for their members, are structured to secure a range of important freedoms for all of their members, even when doing so requires interfering with the freedoms of some of their members. For example, consider laws against assault. Such laws are designed to help protect people against assault, where assault is understood characteristically as intentionally acting to cause serious physical injury to another person. Whenever such assaults occur, they result in morally unacceptable distributions of freedom. What happens is that the freedom of the assaulters, a freedom no one should have, is exercised at the expense of the freedom of their victims not to be assaulted, an important freedom everyone should have. ${ }^{21}$

Sterba then suggests that political states that have as a high priority the securing of justice for their citizens will have mechanisms in which they punish the assaulters, but more importantly, which prevent or limit the abuse of freedom such as the one cited above. He appeals to an understanding of a just society that prizes individual freedom. On the one hand, such a society is structured in such a way that it secures a wide range of freedoms for its citizens. Nonetheless, in doing so, it restricts the freedom of individuals who aim to harm other citizens. Freedom from assault is a freedom a just society endorses even though upholding it restricts the freedom of other individuals.

Sterba implies that just as good, morally motivated governments (more accurately, those human beings who occupy that appropriate morally salient role in such governments) limit the free activities of their citizens, so God should intervene to limit the evil we human beings do and experience. In so far as we see little to no evidence of such interventions taking place, we can infer that either God is not morally good or God does not exist. That is, Sterba suggests something along the lines of the following argument, which I will label Argument B.

Argument B: A Mistaken Analogy

(1) The politically liberal state has an obligation to provide for its citizens those goods to which they have a right, when it can be done easily, and doing so does not violate the morally significant rights of others.

(2) God's governance of the universe is analogous to the head of a politically liberal state.

(3) God is a being perfect in power, knowledge, and goodness-a good God.

(4) If a good God exists and created human beings, then God is obligated to provide for the well-being of human beings just as the head of a politically liberal state is obligated to provide for the well-being of its citizens, as best as he or she is able.

(5) If God is obligated to provide for the well-being of human beings, then God is able to provide all human beings those goods to which they have a right without violating the morally significant rights of other human beings.

(6) It is not the case that most human beings possess the goods to which they have a right and which constitute their well-being.

(7) Therefore, either God is derelict in God's duties with respect to human beings or God does not exist.

(8) It is not possible that a being perfect in power, knowledge, and goodness is derelict in their duties with respect to human beings. 


\section{(9) Therefore, God does not exist.}

Should a believing theist concede that this argument demonstrates that her or his belief in God is logically inconsistent and, thus, irrational? I do not think so. While, on the one hand, I affirm that to address this issue adequately, the discussants must address the relevant ethical concepts that bear on the issue, I hope to show that Sterba has misconstrued their implications. Let me explain why.

In short, Sterba accepts, and invites his readers to accept, the idea that God's governance of the universe is best understood as analogous to the good governance of a politically liberal society, perhaps such as that of the United States, with the powers of government guided and limited by concepts such as individual freedom, natural and legal rights and their correlative duties, and due process, among others. ${ }^{22}$ However, now we have identified the rub. As much as most Christians accept the importance of these concepts for citizens and for those that govern the citizens, especially in democratic societies, Christians do not, nor should they, regard a head of government of a politically liberal society as an adequate analogy for God's governance of the universe. ${ }^{23}$ The positive point of various arguments for God's transcendence or metaphysical uniqueness is that there is an important metaphysical difference between God and creatures. That there are such significant metaphysical differences between God and human beings is alluded to vividly by Psalm 113. In it we read, " ... The Lord is high above all nations, and his glory above the heavens. Who is like the Lord our God, who is seated on high, who looks far down on the heavens and the earth". ${ }^{24}$ Here, the ancient Hebrews envisioned a mighty King whose knowledge and power extends over all things and whose moral goodness is deeper, more powerful, and more unified than the moral goodness of human beings. Moreover, as sovereign of all creation, they envisioned God as unconstrained by anything except God's own nature and the nature of human beings, those God created and desires to flourish. ${ }^{25}$ In Psalm 146, using moral concepts drawn from the assessment of human agents and their acts, the Psalmist asserts that

God keeps faith forever, executes justice for the oppressed, gives food to the hungry, sets prisoners free, opens the eyes of the blind, lifts up those who are bowed down, watches over strangers, and upholds the orphan and the widow. ${ }^{26}$

Suppose you think that our current economic and political arrangements in the United States encourage and support practices that permit, or condemn, a significant number of our fellow citizens to suffer economic and social deprivations. Suppose you also think, from the vantage point of the rights and duties of citizens in a liberal democracy and the powers and responsibilities of those that govern us, that those of us who are well-off should advocate for those much less well-off and, additionally, petition those that govern us to do more to increase the welfare and prospects of our fellow citizens. Suppose you also fault the former or present occupant of the office of the President of the United States (justly or unjustly) for doing too little to improve the lives of millions of fellow Americans whose living conditions significantly diminish their prospects of flourishing. Clearly, you doubt the President's efficacy in addressing these civil ills and, thus, fault his or her knowledge of how to address these concerns adequately or effectively or the strength of his or her moral commitments to address those ills.

When one expresses such morally motivated concerns, we are assuming that our advocacy for our fellow citizens fulfills obligations we have as occupants of a variety of morally salient roles in relation to our fellow Americans (fellow citizen, child of God, friend, human being, neighbor, etc.). If God is analogous to the President of the United States, then God, like the person occupying the morally salient role of "President of the United States" is responsible to all human beings for using all of God's resources to improve the lives of human beings (perhaps other creatures also) under God's governance. However, contends Sterba, obviously, God is not doing all God can to improve, preserve, and protect the lives of His human creatures. All too many suffer horrendous evils. If a good God existed, such evils would not exist. They do exist; therefore, God does not exist. 
However, the disanalogy between God and a human being serving as a king or as a democratically elected head of state is obvious. God has no constraint on the time frame within which God can and must accomplish the good ends God intends for human beings. A head of state is constrained by his or her time in office and the possession of effective political influence with respect to achieving those good ends. That God has no temporal constraints, unlike human political agents, to my mind, is a significant objection to Sterba's argument and an issue we will revisit later in the paper.

\section{Marilyn Adams on Horrendous Evils}

Sterba gives a variety of arguments whose conclusion is that God does not exist, given the kinds and amounts of evil in our world. His primary argument is as follows.

Argument C: The Argument from Horrendous Evils:

(1) If God exists, then horrendous evils do not exist.

(2) Horrendous evils exist.

(3) Therefore, God does not exist.

Marilyn Adams defines horrendous evils as "evils the participation in which (that is, the doing or suffering of) constitutes prima facia reason to doubt whether the participant's life could (given their inclusion in it) be a great good to him/her on the whole"27. This is a formidable argument, given that the argument is valid and premise (2) is obviously true. However, one can block Sterba's contention that the existence of horrendous evil is logically inconsistent with the existence of a God, a Being who is maximally perfect in knowledge, power, and moral goodness. To do so, one insists that God has morally permissible reasons for permitting the kinds and particular incidences of evil that God in fact permits. One's insistence does not require that God's advocate/apologist be satisfied that he or she can provide a complete list of God's morally sufficient reasons for permitting the horrendous evils, which, to our laments, are so characteristic of the world in which we live. ${ }^{28}$ Equally important, what God's advocate also believes is that whatever evils one has endured in this earthly life, God can overcome them in such a way that even for the person who has endured horrendous evils in his or her life, that person is capable of experiencing his or her life as a great good without trivializing the horrendous evils he or she has experienced. ${ }^{29}$ This is why one's inability to provide a complete list of morally sufficient reasons for the kinds of evil we identify in the world is not, ultimately, a defeater. Again, if it is logically possible that God can overcome the horrendous evils all too often suffered by all too many people and God can overcome them in such a way that each person experiences his or her life as a great good despite including in it the suffering of horrendous evils, ${ }^{30}$ then it is false that Sterba has demonstrated that the existence of horrendous evils is inconsistent with the existence of a good God.

\section{Meticulous Divine Intervention and the Horns of a Dilemma}

Sterba disagrees. He presses his case against theism with another example of horrendous evil from the actual world, the case of Matthew Shepard. Sterba reports that

... Matthew Shepard was befriended by two men in a bar in Laramie, Wyoming in 1998. The two men, who were reportedly anti-gay, offered to give Shepard a lift and then drove him to a remote location where they robbed, severely beat, and tortured him, and left him to die hanging on a fence, where he lapsed into unconsciousness and was discovered the next day by a passing cyclist who thought he was a scarecrow. Shepard died two days later in a Laramie hospital never having regained consciousness." ${ }^{\prime 31}$

Then, Sterba suggests that God could have intervened in this case by causing the car of Shepard's assailants to have a flat tire or by causing Shepard to get a ride with someone else or by causing Shepard to walk to his lodging on the University of Wyoming campus. ${ }^{32}$ Additionally, despite Shepard's potential loss of morally significant freedom with respect to these particular actions, a significant balance of good over evil, overall, would be achieved 
by this kind of divine action, especially when one focuses on Shepard's death when compared to his or his perpetrators' temporarily diminished freedom. Sterba concludes,

So clearly with respect to the broad range of actual cases in the world, God has not chosen to secure the freedoms of those who are morally entitled to those freedoms by restricting others from exercising freedoms that they are not morally entitled to exercise. As a consequence, significant moral evil has resulted that could otherwise have been prevented. So, if God is justified in permitting such moral evils, it has to be on grounds other than freedom because an assessment of the freedoms that are at stake would require God to act preventively to secure a morally defensible distributions of freedom, which, of course, God has not done. So, if God is to be justified with respect to cases like Matthew Shepard's, it must be because there is a justification for God's inaction in terms other than freedom because of an assessment of the freedoms that are at stake would require God to act preventively to secure a morally defensible distribution of freedom, which of course, God has not done. It would have to be a justification for permitting moral evil on the grounds that it secures some other good or goods in this life or other goods in an afterlife. Now I am not contesting the possibility of that sort of justification for moral evil in our world here. ${ }^{33}$

What Sterba argues here is that God should have intervened to prevent Shepard's vicious killing. However, if in it, then why not in every vicious human activity? The logical consequence is that God ought to be continually intervening in human affairs when human beings intend to act in morally vicious ways. To me, this implies a serious diminishment of morally significant human actions, carried out as meticulously as Sterba suggests. To block this criticism, what Sterba advocates is "constrained intervention". ${ }^{34}$ Sterba admits that it is reasonable to permit some evils that good may come. I see two problems. First, what criteria is God to use to distinguish between those cases in which divine intervention is required by Divine Goodness, according to Sterba's standards, and those in which divine interventions are not required? Second, the Pauline Principle holds that "we should never do evil that good may come of it". ${ }^{35}$ However, if God's goodness requires strictly following the Pauline Principle, then meticulous divine intervention is always required, is it not? Is Sterba now on the horns of a dilemma? Either significant human freedom or meticulous divine intervention?

\section{A Compensatory Response to the Problem of Evil}

To strengthen his case against God, Sterba invites us to consider another analogy:

"Suppose ... there were among us persons with superhuman powers for making our societies more just than they are ... like Superman, Wonder Woman, SpiderMan, and Xena ... Would we not expect them to do what they can to make our societies more just than they are, and thereby bring about a better distribution of significant freedom?"36

He then asks, "Why then, in the actual world, couldn't God, like superheroes in our fictional world, be more involved in preventing evils that result in the loss of significant freedom for their victims?"37 Indeed, whatever superhuman powers Superman, Wonder Woman, Spider Man, and Xena possess, if God exists, God has infinitely more power than all of them taken collectively. ${ }^{38}$

It is easy to grasp Sterba's suggested argument. If God is perfect in power, knowledge, and moral goodness (a good God), then God is more powerful than any of the superheroes we admire for intervening to prevent horrific evils. If we expect superheroes to intervene to prevent horrific evils, when they are able to do so, then we ought to expect God all the more to intervene in human affairs to prevent horrific evils. However, God does not intervene (very often, as far as we know) to prevent horrific evils. ${ }^{39}$ Therefore, when we think about horrific evils that God permits, we ought not to admire God with respect to his 
governance of our world. Indeed, we should concede that God does not exist, given the amount of horrific evil in the world.

As I have already pointed out, Sterba also appeals to the Pauline Principle to press his case against theism. According to the Pauline Principle, one is not permitted to commit evil, typically, that good may come of it. ${ }^{40} \mathrm{He}$ then comments that "good can come of evil in two ways. It can come by way of preventing evil or it can come by way of providing some new good." ${ }^{41}$ In the case of Matthew Shepherd, it comes, if it comes at all, via the preventing of evil. In his case, the intervention did not occur and Matthew Shepherd suffered a horrifically awful death, and we ask: Where was God?

All these arguments share a common feature. They assume that since God is a moral agent, that His actions to benefit the welfare of human agents must be initiated and completed within the lifetime of God's human beneficiaries. However, this assumption is not a belief internal to the theistic faiths. In particular, Christians believe that God has an infinite amount of time to compensate human beings for the evils, both horrendous and non-horrendous, each has suffered. Thus, it is consistent to claim that not only are these evils defeated in some global way, but, with respect to each individual, the evils he or she has suffered are defeated and redeemed, a particular new good. ${ }^{42}$ Since the faithful have an infinite amount time with God after their earthly pilgrimages have ended, God has an infinite amount of time to accomplish this great new good. Call this the Compensatory ${ }^{43}$ Response to the Problem of Evil. ${ }^{44}$ It is well expressed by Alexander Pruss in a blog called "The Blink Response to the Problem of Evil." He says,

I want to confess something: I do not find the problem of evil compelling. I think to myself: Here, during the blink of an eye, there are horrendous things happening. But there is infinitely long life afterwards if God exists. For all we know, the horrendous things are just a blip in these infinitely long lives. And it just doesn't seem hard to think that over an infinite future that initial blip could be justified, redeemed, defeated, compensated for with moral adequacy, sublated etc. ${ }^{45}$

Pruss endorses the view that the goods of an orderly universe, human autonomy or freedom, and soul building justify God's permitting many of the moral evils so characteristic of human history. He says,

They all have reasonable stories about how the permission of evils is needed for these goods. There is, in mind, only one question about these theodicies: Are these goods worth paying such a terrible price, the prices of allowing these horrors (horrendous evils)? ${ }^{46}$

Pruss suggests that we Christian believers may believe that the question of price is undercut for two reasons.

First, the goods gained by soul building and free will last an infinite amount of time. It will forever be true that one has a soul that was built by these free choices. And the value of orderly laws of nature includes an order that is instrumental to soul building as well as aesthetically valuable in itself. The benefits of the former order last an eternity, and the beauty of the laws of nature - even as exhibited during the initial blink of an eye-last forever in memory. It is easy for an infinite duration of a significant good to be worth a very high price.

Second, it is very easy for God to compensate people during an infinite future for any undeserved evils they suffered during the initial blip. And, typically, one has no (moral) obligation to prevent someone's suffering when (a) the prevention would have destroyed an important good and (b) one will compensate the person to an extent much greater than the sufferings. The goods pointed out by the theodicies are important goods, even if we worry that permitting the horrors is too high a price. And no matter how terrible these short-term sufferings wereeven if the short period of time, at most a century, "seemed like eternity"-infinite time is ample space for compensation. ${ }^{47}$ 
Both these points made by Pruss are internal to the theistic traditions. For example, consider Psalm 8, from the Hebrew scriptures:

O Lord, our Lord,

How majestic is Thy name in all

the earth,

Who hast displayed Thy splendor

above the heavens!

$\ldots$

When I consider Thy heavens,

the work of Thy fingers,

The moon and the stars, which

Thou hast ordained;

What is man, that Thou does take

thought of him?

And the son of man, that Thou

dost care for him? ${ }^{48}$

From the New Testament, consider what the Apostle Paul says in Romans,

For I consider that the sufferings of this present time are not worthy to be compared with the glory that is to be revealed to us. For the anxious longing of the creation waits eagerly for the revealing of the sons of God. For the creation was subject to futility, not of its own will, but because of Him who subjected it, in hope that creation itself also will be set free from its slavery to corruption into the freedom of the glory of the children of God. For we know that the whole creation groans and suffers the pains of childbirth together until now. And not only this, but also we ourselves, having the first fruits of the Spirit, even we ourselves groan within ourselves, waiting eagerly for our adoption as sons, the redemption of our body. For in hope we have saved, but hope that is seen is not hope; for why does one also hope for what he sees? But if we hope for what we do not see, with perseverance we wait eagerly for it ... And we know that God causes all things to work together for good to those who love God, to those who are called according to his purposes. ${ }^{49}$

Additionally, another response from St. Paul to the problem of evil:

But we have this treasure in earthen vessels, that the surpassing greatness of the power of God and not from ourselves; we are afflicted in every way, but not crushed; perplexed, but not despairing; persecuted, but not forsaken; struck down, but not destroyed; always carrying about in the body the dying of Jesus, that the life of Jesus may be manifested in our body. For we who live are constantly being delivered over to death for Jesus's sake, that the life of Jesus also may be manifested in our mortal flesh. So death works in us, but life in you. But having the same spirit of faith, according to what is written, "I BELIEVED; THEREFORE I SPOKE," we also believe; therefore we speak; knowing that he who raised the Lord Jesus will raise us also with Jesus and will present us with you ... Therefore we do not lose heart, but though our outer man is decaying, yet our inner man is being renewed day by day. For momentary, light affliction is producing for us an eternal weight of glory far beyond all comparison, while we look not at the things which are not seen; for the things which are seen are temporal, but the things which are not seen are eternal. ${ }^{50}$

Now, an interlocuter may object by suggesting that compensation implies a wrong being made right. If this is true, then God is implicated in the wrong being righted, and thus, God exhibits a moral imperfection. Moreover, since the classical or traditional Christian view 
is that evil is a consequence of sin, who does God have to compensate? Let me respond, briefly, to these two concerns.

First, The New Oxford American Dictionary defines compensation as "something ... awarded to someone as a recompense for loss, injury or suffering." The something received is addressing the loss, injury, or suffering in some fitting way, given the circumstances. From this definition, it does not follow that the one doing the compensating is implicated as a cause of the loss, injury, or suffering. A generous employer might respond to a loyal worker's injury with a paid leave or money to help while the worker is unable to work. It is possible that the injury was caused neither by the employer nor the employee's negligence. Yet, the beneficent employer addresses the injury in a compensating manner, with no implication that he or she is at fault in any way.

Second, rather than asking, "to whom does God owe compensation?", let us ask, "How will a good God respond to the evil that those God created and loves have suffered?" In his rich and provocative The Divine Conspiracy: Rediscovering Our Hidden Life in God, Dallas Willard argues that

This present universe is only one element in the kingdom of God. But it is a very wonderful and important one. And within it the Logos, the now risen Son of man, is currently preparing for us to join him (John 14.2-4). We will see him in the stunning surroundings that he had with the Father before the beginning of the created cosmos (John 17:24).

We will not sit around looking at one another or at God for eternity but will join the eternal Logos, "reign with him," in the endlessly ongoing creative work of God. It is for this that we were each individually intended, as both kings and priests (Exod. 19:6; Rev 5:10).

Thus, our faithfulness over a "few things" in the present phase of our life develops the kind of character that can be entrusted with "many things." We are, according, permitted to "enter into the joy of our Lord" (Matt. 25:21). That "joy" is, of course, the creation and care of what is good, in all its dimensions ${ }^{51}$

I see no reason to think what is represented by Willard presents a logically impossible state of affairs. It presents a possible way in which God compensates those who have suffered. The experience described by Willard will defeat experienced evils by absorbing, overshadowing, and redeeming the evils each person experienced by reference to what is good in all its rich and robust dimensions. ${ }^{52}$

Perhaps anticipating something such as the compensatory response to the problem of evil, Sterba says, in his discussion and critique of the soul-making theodicy,

What then could God give those deprived of the opportunities for soul-making in this life? Well, then God could give them what we could call them, in contrast to the goods we have just considered, consumer goods, that is, experiences and activities that are intensely pleasurable, completely fulfilling, and all encompassing. Surely the beatific vision, which is said to involve ultimate communion or friendship with God, would presumably be the primary consumer good that would be experienced and enjoyed by those in the traditional heavenly afterlife. ${ }^{53}$

Notice Sterba's choice of words in describing an intrinsic feature of a theistic perspective. He describes the supreme good for the faithful, a life after death that includes union with God and other friends and friends of God, as a consumer good. Now, "consumer good" sounds pejorative to me, a kind of ridicule of, or the demeaning of, a point of view. One way of hearing it is that a consumer good is something regarded as good by someone willing to buy and use it, but it not really a good for the person buying it or it is a second-rate good, compared to other possible goods. However, one acceptable meaning of "consumer good" is a final good, the end result of production and manufacturing of a good or, more generally, the fitting end of a good agent's activity whose product is a real good for the agent and for others, when they possess it. Surely the beatific consummation is a final 
good in the latter meaning of the phrase. Therefore, let us understand "consumer good" as a final good, a new good, which includes a fitting compensation for the suffering of the faithful, though it is much more than that.

\section{Conclusions}

Sterba offered a number of probing, provocative arguments whose conclusions are that a good God does not exist. I am moved by his moral sensibilities and especially by his moral concern for the poor and the politically misused and neglected, given the affluence and power of our shared American culture. However, Sterba dismisses the logical possibility that a good God is able to compensate all victims of horrific evils in a way fitting to each of them. I see no reason to accept that God cannot compensate the victims of horrific evils in these ways. After all, a good God has the requisite power and knowledge, and an infinite amount of time to accomplish this awesome task by absorbing, defeating, redeeming, and thus, compensating each human being for any horrendous evils he or she has suffered. In short, my defeater presumes that God can secure for a human being genuine goods, not only in this life, but also in the life to come, the most important of which is enjoying God, the Supreme Good, and His divine presence, in the company of other saints, eternally; a new good. ${ }^{54}$ The richness of this communion is what is sometimes called beatitude. This assumption is legitimate for Christian theists of a traditional sort, since it is an essential component their beliefs. Early on in his book, Sterba notes that he is not contesting the possibility of a moral justification for God's permitting horrendous evils, one of which might be that God's permitting them "secures some other good or goods in this life or other goods in an afterlife." ${ }^{\prime 55}$ Given the logical possibility that human beings who have suffered horrific evils will enjoy God's Divine Presence in the company of other human beings united in friendship with one another and with God, eternally-and this possibility is an essential constituent of traditional Christian theism - the existence of God is logically compatible with the existence of horrific evils. ${ }^{56}$

Funding: This research received no external funding.

Institutional Review Board Statement: Not applicable.

Informed Consent Statement: Not applicable.

Data Availability Statement: Not applicable.

Conflicts of Interest: The author declares no conflict of interest.

\section{Notes}

(Sterba 2019, p. 1).

(Adams 1999).

(Sterba 2019, p. 1).

In the book, by "good God", Sterba means a Being maximally perfect in knowledge, power, and moral goodness.

Some theists affirm that the assertion "God is the Good" is a metaphysical claim, which may or may not entail moral goodness. One such proponent is Robert Adams. See (Adams 1999, especially Chapter 1, pp. 13-49 and Chapter 2, pp. 50-82).

6 (Davies 1982, p. 22).

7 (Davies 2006, p. 103).

8 (Davies 1982, p. 23).

9 For a rigorous defense of this position, see (Davies 2011, chapter six).

10 (Barth 1957, p. 311).

(Barth 1957, p. 189).

(Martin 1960, pp. 17-18).

(Ward; Scotus 1987, p. 19)

14 See, St. Thomas Aquinas, Summa theologiae 1.13.5 (Hause and Pasnau 2014). I am grateful to my colleague, Tom Ward, for suggesting this quote from Aquinas. It supports Ward's contention that Aquinas' view on analogy aligns decisively with Scotus' view about how our language works when we speak about God and human beings. 
(Lewis 2001, p. 29).

My insertion is to make explicit Lewis' clear meaning of this paragraph.

(Lewis 2001, p. 32).

Of course, it is possible that the similarity between God and human beings is sufficient to ground analogous predications of goodness but not strong enough for univocity. Like Sterba, I accept the univocity thesis with respect to a wide range of moral properties asserted of both God and human beings. In doing so, both Sterba and I join Marilyn Adams and Richard Swinburne and the mainstream of the Christian theological tradition in accepting that God's agency is personal, an agency that acts by thought and will. See (Swinburne 1979, pp. 22-50) and (Adams 1999, pp. 62-70; 80-82).

That is, the part of Divine Goodness that is moral goodness.

I regard Plantinga's "free will defense" as having a limited but important usefulness in the discussion of the problem of evil. I accept Sterba's rejection of the free will defense as an adequate response to horrendous evils. Of course, Plantinga never offered it as such. While Sterba devotes considerable attention to Marilyn McCord Adams' treatment of the problem of evil in her (Adams 1999), it seems odd to me that he ignores or fails to address the central themes in (Stump 2010). (Sterba 2019, p. 13).

That many of the dissenters to the Catholic and Protestant churches insisted on natural rights and a kind of political equality is no surprise since each of us bear the image of God.

I fear being misunderstood on this point. I do not mean to suggest that Christians do not think of God as analogous to a ruler or a king of a Kingdom. The Bible uses that imagery, not surprisingly, a great deal. My point is that that thinking of God governance of the Universe as analogous to the governance by the head of state of a political liberal democracy is an inadequate or misleading analogy.

Psalm 113:4-6, (Coogan 2010).

I affirm that God's good will is directed not merely toward human beings to all God's creation. After all, in Genesis 1:31, we find that God affirmed that all that God made was very good. An ethically provocative treatment of the implications of God's affirmation of the goodness of the created order is found in "Shalom and the Community of Creation," in (Woodley 2012, pp. 41-66).

Psalm 146: 7-9.

(Adams 1999, p. 26). This definition first appeared in her essay, "Horrendous Evils and the Goodness of God", in (Adams and Adams 1990, pp. 209-21).

See (Adams 1999, p. 155).

Ibid., p. 156.

Ibid., pp. 155-56.

(Sterba 2019, p. 20).

Ibid., p. 21.

Ibid., pp. 23-24.

Ibid., p. 90.

Ibid., p. 49.

Ibid., p. 19.

Ibid., p. 20.

To the theist, the analogy will be at best limited, and, at worst, demeaning, a false analogy, and impious.

Perhaps we should be skeptical about how much we know about how much God intervenes to prevent evil, both ordinary and horrific evils.

(Sterba 2019, p. 56).

Ibid. On my reading of Sterba on this point, sometimes the provision of a new good overrides the Pauline Principle. More importantly, that when God permits evil, it is not God's doing evil that good may come of it. God is not the agent doing evil.

See the text referenced by footnote 39, in which Sterba suggests that it is permissible for a new good to be a satisfactory response to some instances of evil.

In her rich and important book, Wandering in Darkness: Narrative and the Problem of Suffering, Eleonore Stump says, in comparing a possible world in which God permits suffering, hence evil, and a possible world in which God does not, that the former, her stories show, possess a "great compensatory beauty". The compensatory beauty does not provide God, however, on Stump's account, a morally sufficient reason for permitting the evils God in fact permits. It merely explains one reason why allowing or permitting moral evils is not a defeat for a good God. Both Stump 
and I are appealing to the concept of compensation or a compensatory aspect to God's governance of the world. However, my use is somewhat different that Stump's. However, I commend Professor Stump's book to the reader, both for its profundity and for the ways in which it is an antidote to the notion that the existence of suffering, hence, moral evil, is incompatible with the existence of a good God (Stump 2010).

44 I first formulated something like this response in an unpublished paper called "The Problems of Evil". In it, I addressed what I called the "existential problem of evil" and posed the possibility of a "delayed divine deliverance" from evil.

45 (Pruss 2017).

46 (Pruss 2017).

$47 \quad$ Ibid.

48 Psalm 8, (Coogan 1977).

49 Romans 8:18-25; 28, (Coogan 1977).

502 Corinthians 4:7-14; 16-18, (Coogan 1977).

51 (Willard 1998, p. 378).

52 C. S. Lewis gives us an arresting and evocative picture of our union with God in the last two chapters of his book, The Last Battle. See, Lewis (2005). The chapters are entitled, "Further Up and Further in" and "Farewell to Shadowland", pp. 755-67.

53 (Sterba 2019, p. 36).

54 See footnote 39.

55 (Sterba 2019, p. 24).

56 See also, James H. Cone, “The Meaning of Heaven in the Black Spirituals”, in (Cone 1992, pp. 78-96). In this chapter, he asks, "How was it possible for black people to endure the mental and physical stresses of slavery and still keep the humanity intact? I think the answer is found in their image of heaven".

\section{References}

Adams, Marilyn McCord, and Robert Adams, eds. 1990. The Problem of Evil. Oxford: Oxford University Press. Adams, Marilyn McCord. 1999. Horrendous Evils and the Goodness of God. Ithaca and London: Cornell University Press. Adams, Robert. 1999. Finite and Infinite Goods: A Framework for Ethics. Oxford: Oxford University Press.

Barth, Karl. 1957. Church Dogmatics. Edinburgh: T. \& T. Clark.

Cone, James H. 1992. The Spirituals and the Blues: An Interpretation. Maryknoll and New York: Orbis Books.

Coogan, Michael D., ed. 2010. The New Oxford Annotated Bible, Fully Revised 4th ed. Oxford: Oxford University Press.

Coogan, Michael D. 1977. Holy Bible: New American Standard. Edited by The Lockman Foundation Editorial Board. Nashville: Holman Bible Publishers.

Davies, Brian. 1982. Introduction to the Philosophy of Religion. Oxford: Oxford University Press.

Davies, Brian. 2006. The Reality of God and the Problem of Evil. London and New York: Continuum.

Davies, Brian. 2011. Thomas Aquinas on God and Evil. New York: Oxford University Press.

Hause, Jeffrey, and Robert Pasnau, eds. 2014. Aquinas: The Basic Works. Indianapolis: Hackett Publishing Company.

Lewis, Clive Staples. 2001. A Grief Observed. New York: HarperCollins Publishers, Inc.

Lewis, Clive Staples. 2005. The Chronicles of Narnia. New York: HarperCollins Publishers, Inc.

Martin, Charles Burton. 1960. Religious Beliefs. Ithaca: Cornell University Press.

Pruss, Alexander R. 2017. The Blink of an Eye Response to the Problem of Evil. Available online: alexanderpruss.blogspot.com/2017/0 8/the-blink-of-eye-response-to-problem-of.html (accessed on 25 August 2017).

Scotus, John Duns. 1987. "Duns Scotus." Philosophical Writings: A Selection. Translated and Edited by Allan B. Wolter. Indianapolis: Hackett Publishing Company.

Sterba, James P. 2019. Is a Good God Logically Possible? Cham: Palgrave MacMillan.

Stump, Eleonore. 2010. Wandering in Darkness: Narrative and the Problem of Suffering. Oxford: Clarendon Press.

Swinburne, Richard. 1979. The Coherence of Theism. Oxford: Clarendon Press.

Ward, Thomas M. Forthcoming. Ordered by Love: An Introduction to John Duns Scotus. Brooklyn and New York: Angelico Press.

Willard, Dallas. 1998. The Divine Conspiracy: Rediscovering Our Hidden Life in God. New York: HarperCollins Publishers Inc.

Woodley, Randy S. 2012. Shalom and the Community of Creation: An Indigenous Vision. Grand Rapids: William B. Eerdmans Publishing Company. 